\title{
Recreation And Commodification Of The Palang Pintu Tradition In The Betawi Cultural Heritage Of Rawa Belong Analysis Of Sanggar Gaya Bang Bens
}

\author{
Diaz Ramadhansyah ${ }^{1 *}$, Nuning Yanti Damayanti ${ }^{2}$
}

\author{
${ }^{1}$ Institut Teknologi Bandung \\ ${ }^{2}$ Institut Teknologi Bandung \\ *Corresponding email: diazrama@gmail.com
}

\begin{abstract}
Jakarta as the center of government and economy of Indonesia is a multicultural city, which was formed by the combination of various ethnic groups who inhabited the Jakarta area. Hence, Betawi ethnicity which is known as the original inhabitants of the city of Jakarta, is actually an ethnic group formed from the acculturation process of various ethnic groups in Indonesia and outside Indonesia. One aspect that stands out in Betawian culture is the influence of Islamic religious culture which was spread by ethnic Arabs. However, along with the times, the cultural forms of the Betawi tradition are thought to have changed from their initial form. One of them is the Palang Pintu tradition, which was originally part of a traditional Betawi wedding ceremony and is very strong with Islamic values, now it can be presented for building inauguration events or investiture ceremonies. There has been a transformation in the function and practice of the Palang Pintu tradition in modern times in Jakarta.

This research refers to the theory of cultural commodification to explain how the Palang Pintu tradition has now become a cultural commodity through sanggar budaya activities, as well as using qualitative methods and field research that focuses on Sanggar Gaya Bang Bens and its activities in the Rawa Belong area. Field research and interviews show that the development of sanggar and foundations is an effort to preserve and develop Betawi culture. In addition, modifications were also made to the Palang Pintu tradition to make it a livelihood for the Betawi people in Rawa Belong. Lenong and Pantun (poem) elements are very important supporting aspects in the preservation of the Palang Pintu tradition, so this tradition is constantly being attractive and gaining popularity among modern society.
\end{abstract}

Keywords: Betawi, Commodification, Palang Pintu, Rawa Belong, Recreation

\section{INTRODUCTION}

Betawi ethnicity is the original inhabitants of the city of Jakarta that has been formed through various acculturation processes of the ethnic groups that had previously inhabited the Batavia area. These ethnicities include Malay, Arabic, Chinese, Portuguese, Indian, Javanese, Sundanese, etc. [1]. This inter-ethnic meeting has played a role in the development of the city of Jakarta since the precolonial era. It indicates that the city of Jakarta was built due to the interaction of these various ethnic groups, thus influencing the culture and traditions created in it, including the birth of a new ethnic group, namely Betawi.

The number of Betawi people in Jakarta is not prominent. For comparison, the Sundanese ethnic group in Bandung dominates as well as the Javanese ethnic in Yogyakarta and Surabaya. In Jakarta, along with its indigenous population, Betawi ethnicity is not dominant in terms of both numbers and roles [2]. Ethnic Betawi live in scattered cities around Jakarta, such as Bogor, Depok, Bekasi, Karawang, and Tangerang. Among these cities, only a few cities have significant Betawi ethnic dominance. The city of Bogor is inhabited by immigrants and nomads. 
But due to its territory as part of West Java, Sundanese ethnicity dominates. In Tangerang and Serang, the Betawi ethnic quite dominant. Meanwhile, in Depok, Bekasi, or Karawang there are too many migrants who work and live there for generations. Despite their domination, Betawi still have to compete with other migrants for a living. The conditions explained above then lead to the emergence of the terms Betawi City, Betawi Tengah, and Betawi Pinggir. That grouping then played a major role in the creation of culture and arts in Jakarta.

Betawi culture and traditions are considered to be complicated, long processes, and require a lot of money. Those stereotype situations also occur to the other cultures and ethnicities in Indonesia. Because of the economic factor, holding traditional ceremonies or traditions is marking the wealthy status of a family. On the other side, along with the modernization that occurs in Jakarta, Betawi culture gradually began to be abandoned. The activities and interests of the younger generation began to turn towards the popular culture that came from abroad, such as birthday parties, international wedding ceremonies, or western songs. Hence to be able to keep carrying out the traditional procession, people started to simplify their traditional ceremonies, for example in the wedding ceremonies.

This modern situation would cause a cultural crisis for Betawi ethnicity. In Shahab [3] it is told that in order to avoid the extinction of Betawi traditions and arts, the Governor of DKI Jakarta Ali Sadikin (1966 - 1972) initiated a process of Reka Cipta or re-creating Betawi traditions. It is explained that the Betawi arts and traditions have undergone a process of recreation. Not only that, Betawi traditions and arts have also undergone a commodification process. It is indicated by the creation of Cagar Budaya Betawi, or Betawi cultural heritage, as a tourism object. Betawi cultural elements such as coconut leaves, Ondel-ondel, or the architecture of traditional housing are often presented as decorations and displayed on DKI Jakarta government buildings to mark Jakarta's identity.

In response to the situation, various Betawi sanggar (cultural studio) began to emerge to intensify their activities and bring the Betawi tradition closer to the community, as well as introduce the Betawi tradition to other ethnic communities in Jakarta. Betawi sanggar have various focuses, such as silat (martial arts), dance, Ondel-ondel, and Palang Pintu. One sanggar that is actively engaged in preserving Betawi culture and traditions is the Yayasan Seni Budaya Gaya Bang Bens, or called Sanggar Gaya Bang Bens. This sanggar, which is based in the Rawa Belong area in West Jakarta, seeks various methods to preserve and develop Betawi culture and traditions by focusing its activities on the Palang Pintu. This tradition is a part of the Betawi wedding ceremony, which is carrying Islamic religious philosophy. In Sanggar Gaya Bang Bens hands, the Palang Pintu tradition is demonstrated not only for Betawi ethnic wedding ceremonies but also for a non-traditional event such as inauguration ceremony or circumcision celebration. This development leads to economical impact for Palang Pintu practitioners. Palang Pintu has been adjusted to become a show that can be enjoyed by a wider community, no longer limited to a wedding party's guests. That is, by Sanggar Gaya Bang Bens, Palang Pintu has undergone a process of recreation and commodification.

The commodification process is then considered as an effective way to preserve and develop a traditional culture, rather than just building a museum or practicing it in the Betawi neighborhood. Previous studies on Palang Pintu have focused on symbols, visual attributes, and the influence of Arab culture and Islam in it. Meanwhile, this study focuses on the practice of Palang Pintu by Sanggar Gaya Bang Bens and intends to offer new data on commodification and adaptation practices that are relevant for the preservation of cultural traditions in the modern era. This study aims to dig into how the process of recreation and commodification is carried out in the Palang Pintu tradition, and how it affects the community and the sustainability itself. This study took samples from the Betawi cultural heritage area of Rawa Belong, with Sanggar Gaya Bang Bens as the interviewees.

\section{RESEARCH METHOD}

The research was conducted using qualitative methods by James P. Spradley through the process of literature study, field research, and interviews with Sanggar Gaya Bang Bens. This study using ethnographic study approach to describe and interpret culture, social group, or system, which investigates a cultural group in a natural environment through primary data collection, observation data, and interview data.

During the earliest stage, literature study focused on the history and origins of the Betawi ethnicity. To analized the commodification process, the basis paradigm used is Norman Fairclough's concept that commodification is the incorporation of new domains into the commodity market [4]. This 
concept follows Theodor Adorno's culture industry theory, which says,

The culture industry fuses the old and familiar into a new quality. In all its branches, products which are tailored for consumption by masses, and which to a great extent determine the nature of that consumption, are manufactured more or less according to plan. (Adorno: Culture Industry Reconsidered on New German Critique 6, Fall 1975, p. 12-19)

Also through Morgan [5], it is explained how Adorno's views that the commodification of culture does not place one type of cultural production over another, but rather the process of how cultural production is commercialized. This theory is considered to be in line with the practice carried out by the Sanggar Gaya Bang Bens, with the modification of Palang Pintu to make it a commodity .

The data collected from literature study was secondary data. Meanwhile, the data obtained through the field research process is primary data. The field research process includes a direct survey of the Palang Pintu performance conducted by Sanggar Gaya Bang Bens and interviews with the founders. During the data analysis stage, a method by Simone Kruger [6] was used by conducting interviews, narrowing the information, and generating data. In the discussion section, this study will see whether the secondary data collected can be proven by primary data.

\section{DISCUSSION}

\subsection{Betawi Ethnicity, History, and Its Classification}

Betawi ethnicity is an ethnic group born from the mixing of various ethnic groups such as Portuguese, Indian, Chinese, Dutch, and so on. The name "Betawi" was first recorded in the 1964 testament of Nyai Inqua, the widow of landlord Souw Beng Kong, the first Chinese Captain in Batavia [7]. Because this community group has existed since the 17th century, Erwantoro concluded that the ancestors of Betawi ethnic group were residents of Jayakarta.

According to Shahab through Anggraeni [8], based on geography and place of residence, the Betawi people are divided into four regions, namely Betawi Tengah, Betawi Pinggir, Betawi Udik, and Betawi Pesisir. The Betawi Tengah group inhabits urban areas such as Gambir, Menteng, Senen, Kemayoran, Sawah Besar, etc., close to the central government area. This group is also referred to Betawi Gedong or Betawi Kota. Furthermore, the Betawi Pinggir group are those who live in suburban areas such as Pasar Rebo, Pasar Minggu, Pulogadung to Cilincing, Condet, Mampang, etc. Betawi Udik are people who live in areas bordering the Sunda-speaking area. Betawi Udik is divided into two groups, (1) influenced by Sundanese culture located in the East and South areas of Jakarta such as Bekasi and Bogor, and (2) influenced by Chinese culture living in North and West areas of Jakarta and Tangerang. The last one, the Betawi Pesisir, are the people who inhabit around Teluk Naga, Mauk, Japad, Tanjung Priuk, Muarunda and the Kepulauan Seribu. Apart from those, Shahab also divided the Betawi elite group, which the Betawi Kota group is a political elite group, while the Betawi Tengah group is a Islamic elite group.

The classification of Betawi group based on geography was also formulated by Bunyamin Ratno through Anggraeni [9], in a more simple way, namely tengah (central) and pinggiran (outskirt) regions. The Tengah region is influenced by Malay and Middle Eastern culture, which influenced Betawi's musical instruments such as Samrah, Zapin, and Rebana. Meanwhile, the pinggiran area is divided into North and South parts. The northern part, which includes North, West, and Tangerang, is influenced by Chinese culture as in its artistic manifestations such as Gambang Kromong, Cokek, and Lenong. While the southern part includes East Jakarta, South Jakarta, Bogor, and Bekasi, influenced by Sundanese culture.

According to Ratno's classification, it is illustrated that Gambang Kromong and Lenong, which are now known as Betawi performing arts, were influenced by Chinese. Shahab [10] also clarifies this assumption that much of Betawi art comes from the Betawi Pinggiran group.

\subsection{The Origin of Palang Pintu Tradition}

Palang Pintu tradition is a relatively new tradition, which the Betawi community began to recognize in the 1990s. The term Palang Pintu, which literally means a wooden block that holds the door from opening, is used as a symbol. The Palang Pintu tradition (or also called Buka Palang Pintu) means a ritual in which the groom and his entourage come to the bride's house and fight the jawara (martial art warriors) who are guarding there. Those jawara are likened to test the groom. If the groom or his assigned jawara can beat the host, then he can go 
ahead and undergo Ijab Kabul (marriage solemnization).

According to Anggraeni, there is no special note about when and where Palang Pintu tradition began. The source of the origin of Palang Pintu tradition is told from generation to generation [11]. Even so, cultural acculturation is manifested in the Palang Pintu tradition which can be seen from its instruments. The clothing used in carrying out Palang Pintu is Pangsi clothes, which is the specific clothes for jawara. This type of clothing is also found in Sundanese and Malay ethnic, and also influenced by Chinese culture.

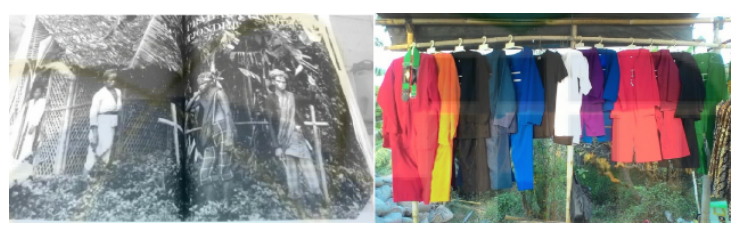

Figure 1 (left) Ancient Jawara's costume; (right) Current Jawara's costume. Source: Wiqoyatul Amanah.

The use of Pangsi clothes in Palang Pintu is distinguished by color: Black for the home group, Red for the visitors, and Green for the Marawis performers. In addition, Amanah [12] said that in this modern era Pangsi cloths evolve into other colors to enlivening Palang Pintu's atmosphere. Other attributes that Jawara wears are peci (hat) and golok (machetes), and Sarung.
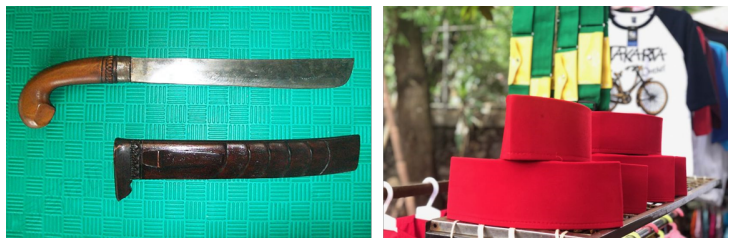

Figure 2 (left) Golok, souce Sejarahjakarta.com; (right) Peci, source Okezone.

The instruments that are often presented at Palang Pintu are Rebana Ketimpring, Kembang Kelapa (coconut tree) decorations, Roti Buaya (crocodile shaped bread), and Petasan (firecrackers). Rebana Ketimpring as a musical instrument in Palang Pintu is sometimes replaced by Marawis, both of which are influenced by Middle Eastern culture.

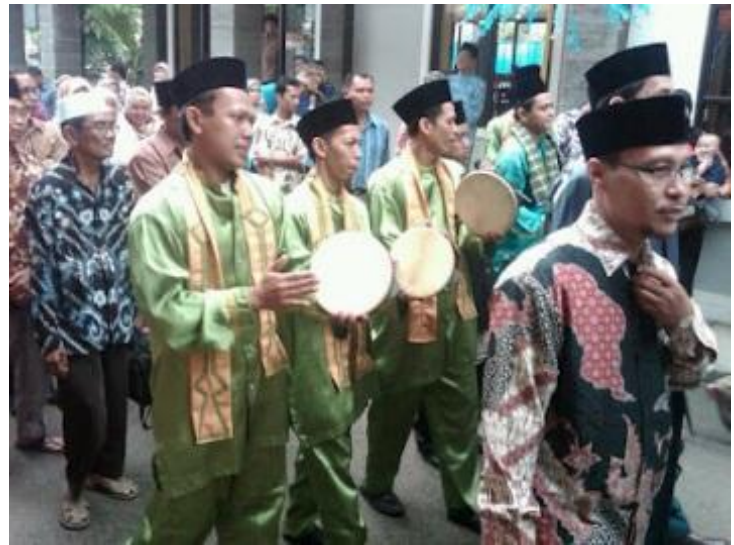

Figure 3 Rebana Ketimpring for Betawi's wedding ceremony. Source: Pustekkom Kemdikbud.

Petasan are often presented to enliven the atmosphere in the groom's procession. This culture is inspired by Chinese culture, such as the Cap Go Meh celebration. Meanwhile, Kembang Kelapa is an embodiment of the Betawi people's philosophy of life. Melinda [13] explains the philosophy of the coconut tree which has benefits from the roots to the fruit. So the hope is that the bridegroom and the bride will always lead a life that brings luck to their married life. Roti Buaya is a crocodile shaped bread which symbolizes a loyal animal. Male crocodiles only marry one female crocodile during his lifespan, so it gives hope that the groom will only marry one bride in his lifetime.

In performance, it is shown by reciprocating rhymes and martial arts. Quoting from Permana [14], pantun first appeared in Malay history, and brought into Betawi culture orally and developed by word of mouth. Acculturation occurred in pantun by the use of the Betawi dialect of Indonesian. And silat, an Indonesian kind of martial art, originated from Chinese martial arts.
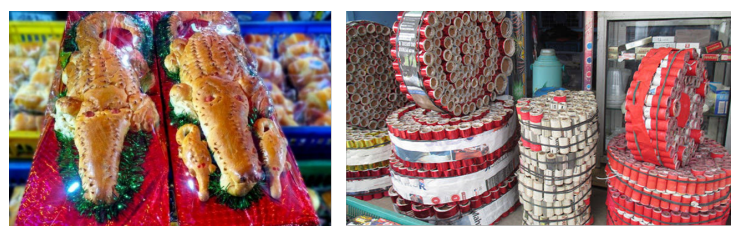

Figure 4 (left) Roti Buaya, souce IDN Times; (right) Petasan, source Okezone.

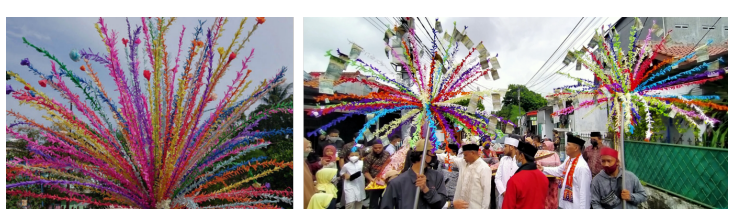

Figure 5 (left) Kembang Kelapa; (right) Kembang Kelapa by Sanggar Gaya Bang Bens attached with Rupiah bills. Source: Setu Babakan and Author. 
Table 1. Stages of Palang Pintu

\begin{tabular}{|l|l|l|}
\hline No. & Stages & Description \\
\hline 1. & $\begin{array}{l}\text { Greetings between the two } \\
\text { representatives of the family. }\end{array}$ & $\begin{array}{l}\text { The host greets the groom's entourage and questions the purpose } \\
\text { of their arrival. The communication used pantun with Betawi } \\
\text { dialect, with common language that is easy for the audience to } \\
\text { understand. }\end{array}$ \\
\hline 2. & Reciprocating Pantun. & $\begin{array}{l}\text { The host conveyed two conditions that must be fulfilled if the groom } \\
\text { wanted to marry their family: silat battle and Al-Quran recitation. }\end{array}$ \\
\hline 3. & SilatBattle. & $\begin{array}{l}\text { Both parties have more than one jawara. The losing jawara is } \\
\text { replaced by a stronger one. This process also includes elements } \\
\text { of comedy. The silat fight drives the emotions of the audience from } \\
\text { tense, laughing, then tense again. After all the jawaras fought each } \\
\text { other, the final battle was won by the jawara from the groom's side. }\end{array}$ \\
\hline 4. & $\begin{array}{l}\text { Reading the holy verses of Al- } \\
\text { Quran. }\end{array}$ & $\begin{array}{l}\text { After fulfilling the requirements for silat, the next is the Al-Quran } \\
\text { recitation. One representative from the groom's side recited the } \\
\text { Quran verses. After the second condition is fulfilled, the groom and } \\
\text { his entourage are invited to enter the house to do ljab Kabul. }\end{array}$ \\
\hline
\end{tabular}

\subsection{Implementation of Palang Pintu Tradition and the Recreation Occurs}

Betawi culture is heavily influenced by the spread of Islam, since most of the Betawi people embrace Islam. On the other side, not all of the the traditions and arts are formed conformable to Islam. This caused a big rejection towards Chineseinfluenced cultures, especially by the people of Betawi Tengah. Hence some cultures need to undergo a rerecreationcreation to be accepted by the community.Reka cipta, according to the Kamus Besar Bahasa Indonesia, is the innovation. Meanwhile, in English term, Oxford dictionary define recreation as the act or process of making something that existed in the past exist or seem to exist again. In the context of cultural discovery, Kirsten Ostherr [15] defines creativity as a series of useful innovative behaviors adopted by people who then pass them on to other people or the next generation. Then, it is assumed that reka cipta is a process of creation and adaptation, making a culture adaptive to the situation and generation.

Shahab [16] gives an example of the recreation experienced by the art of Gambang Kromong. This performing art has been associated with promiscuity, alcohol, and gambling, which is very much at odds with Islam. Therefore when the DKI
Jakarta government tried to promote Gambang Kromong as Betawi music in the 1970s, it received strong rejection from Islam's believer within Betawi people. They do not want to consider things that are contrary to Islam as Betawi culture.

Thus, DKI Jakarta government eliminated the elements that contradict to Islam so that Gambang Kromong can be performed for various events in Jakarta. Gradually Betawi people began to accept Gambang Kromong, and the public began to recognize the existence of Gambang Kromong as a Betawi art. This explained that recreation is an adaptation of a cultural behavior to be fit with its public.

Palang Pintu has several important elements: Silat, Pantun, and Mengaji (reciting Al-Quran). However, two primary elements are silat and mengaji, which associated with Islam. The Palang Pintu in a wedding ceremony is a symbol of the readiness and willingness of a Betawi man to live in the household. Silat becomes a symbol of the world, and mengaji as a symbol of the afterlife. With martial arts skills a husband is believed to be able to protect his family from nuisance. And by the ability of mengaji, a husband is believed to be able to guide his family in worship so that they can enter heaven. A Palang Pintu procession requires at least five personnels: two carrying marawis drum and accompanying the groom's family while chanting 
the Prophet's shalawat (blessings); one person becomes the spokesperson of the group; a jawara; and Al-Quran reciter. The number can increase, especially for jawara. This tradition is only practiced by male performers.

In this modern era, silat skill is no longer necessary even for the Betawi men. Thus, the bride and bridegroom hire the services from sanggar to represent their jawara and perform Palang Pintu on behalf of them.

Figures below give an overview about the costumes of Palang Pintu in 2000 and 2021.

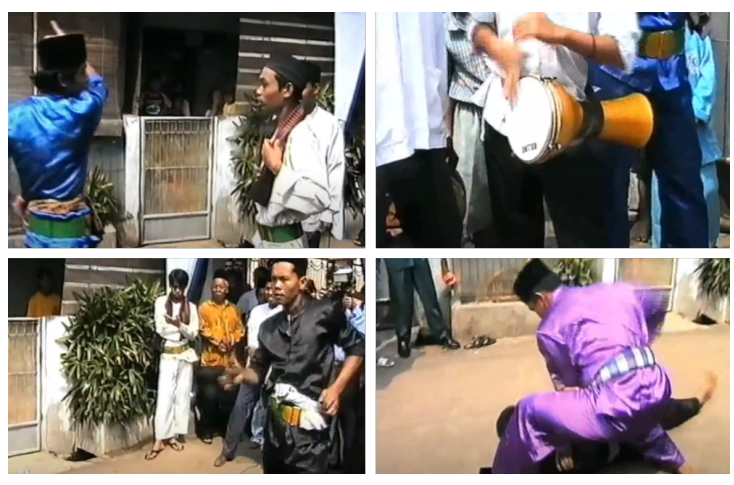

Figure 6 Palang Pintu's costumes by Sanggar Gaya Bang Bens circa 2000s. Source: Sanggar Gaya Bang Bens.

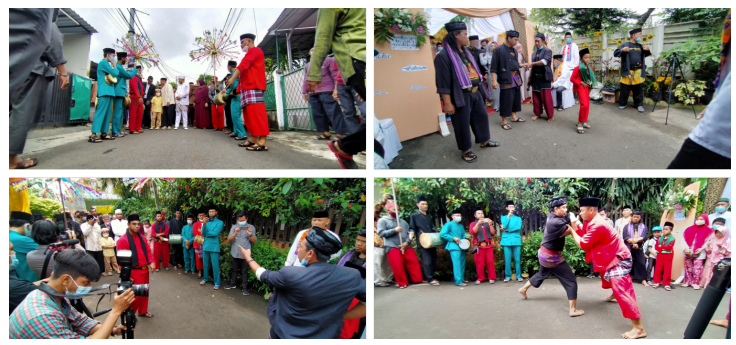

Figure 7 Palang Pintu's performance by Sanggar Gaya Bang Bens in 2021 shows the development of its costumes. Source: Author.

\subsection{Sanggar Gaya Bang Bens and Its Activities in Recreation and Commodification of Betawi Culture}

Yayasan Seni Budaya Betawi Gaya Bang Bens is located in Rawa Belong. On Sunday 4 April 2021, a visit to the Sanggar Gaya Bang Bens office was held to see the Palang Pintu procession in a Betawi traditional wedding ceremony. This sanggar activity has been carried out since the 1980s when those interviewees were young. They came from various martial arts padepokan (school) in the West Jakarta area, who decided to build their own sanggar. The name Sanggar Gaya Bang Bens was inspired by one of its members, named Beni, who has a witty character. Although it has started its activities since the 1980s with a focus on silat, the establishment of a foundation was carried out in 2000 . The use of the word "gaya" (method) indicates that the activities carried out by this sanggar have gone through a modification process. Gaya Bang Bens refers to a practice that is slightly different from the original standard, by creating a certain characteristic.

At its original appearance, the musical instrument that accompanies Palang Pintu was Rebana Ketimpring. In Sanggar Gaya Bang Bens' case, Marawis is used instead of Rebana Ketimpring, due to the limitation of Rebana Ketimpring's performers. The rhyme elements, which initially used Malay Pantun which were full of proverbs, were being modified in terms of content, language, and delivery methods to be understood by the surrounding community. Some Betawi sanggar inserted Lenong and comedy elements to the pantun to make it relevant to modern society. Therefore Palang Pintu becomes more interesting and attractive for a diverse and contemporary society.

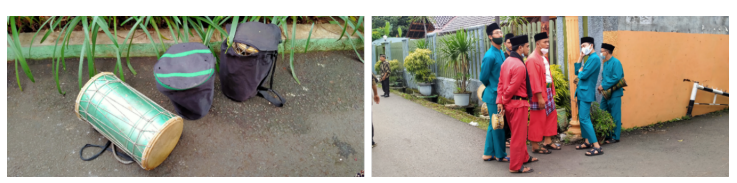

Figure 8 Sanggar Gaya Bang Bens is using

Marawis as its musical instrument in Palang Pintu.

Source: Author.

The Palang Pintu carried out by the Sanggar Gaya Bang tends to adapt to existing conditions. Beside the musical instrument, can also be seen from Pangsi cloth and Kembang Kelapa. Sanggar Gaya Bang Bens uses black Pangsi for the host group, red Pangsi for the guest group, and turquoise Pangsi for the Marawis performers. The quality of Pangsi also depends on where the performance took place. As for the Kembang Kelapa, this studio embeds 2.000 - 5.000 Rupiah notes in it, which can be contested by the audience. They do not use firecrackers for safety reasons. As a cultural foundation, Sanggar Gaya Bang Bens is not only active in preserving the Palang Pintu tradition, but also silat, dance, Marawis, and Lenong. Exercises are held regularly in order to join various events and festivals. However, over the time, the most popular activity performed by this sanggar is Palang Pintu.

The commodification process generally occurs in Betawi culture, through the creation of cultural heritages such as the Setu Babakan Betawi Cultural Heritage, Condet, Rawa Belong, etc. The commodification process of Betawi culture is 
generally carried out by the DKI Jakarta government for tourism purposes, while the commodification of the Palang Pintu tradition occurs through the sanggar and their practitioners. Fairclough through Minawati [17] explained that commodification can be understood as a commodity production process that is not limited to the economic sphere, but can refer to the organization and conceptualization of the production, distribution, and consumption of commodities. More specifically, the Oxford Learner's Dictionary defines commodification as an act or process of treating something as a product of buying and selling. Commodification describes the way capitalism achieves its goals through the accumulation of capital and the transformation of use value into exchange value. This condition was also supported by Adorno's statement through Minawati [18] that commodification does not only refer to consumer goods, but has spread to the arts and culture in general. Thus, correspond to what happened in Palang Pintu tradition.

Palang Pintu which was originally a wedding ritual has now become a public show that can be marketed. Several elements in Palang Pintu are modified according to the needs of consumers or event hosts. Palang Pintu performed as a theatrical performance without losing its essence.

The Rawa Belong area in West Jakarta is one of the Betawi cultural heritage areas designated by the DKI Jakarta government. This determination was made due to the legacy of Si Pitung, the legendary Betawi silat jawara in Rawa Belong. Since ancient times, the Rawa Belong area has been inhabited by ulama (Islamic scholars) and jawara. Before Palang Pintu was known in West Jakarta, the people of Rawa Belong had been actively practicing silat and had established various silat padepokan (school). Palang Pintu, which is so full of silat and Islamic elements, is easily accepted by the people of Rawa Belong.

Malay Pantun that is used in original Palang Pintu is considered not suitable for modern audiences and will make the essence of Palang Pintu difficult to understand. Hence Sanggar Gaya Bang Bens modified their pantun by incorporating Lenong's comedy and theatrical elements. They sometimes adjust the contents of the pantun according to the background of the bride and groom's family. The language is Indonesian with Betawi dialect, so non-Betawi viewers could understand the essence of Palang Pintu well.
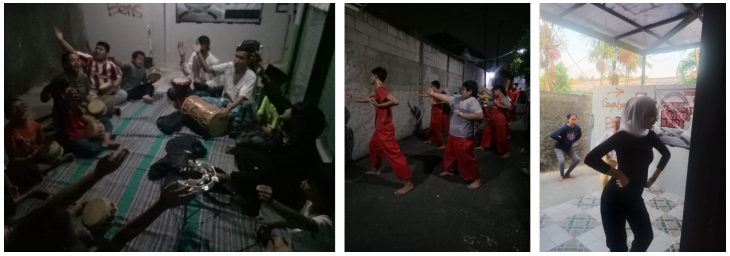

Figure 9 Sanggar Gaya Bang Bens activities such as marawis, silat, dan dance practice. Source: Sanggar Gaya Bang Bens.

\subsection{Foundation Establishment and Promotion Activities}

Sanggar Gaya Bang Bens was established in 2000 to increase its promotions. The sanggar sees that legal status would support them to be able to participate in government's official events and large-scale corporations. Therefore Yayasan Seni Budaya Betawi Gaya Bang Bens was formed. Sanggar Gaya Bang Bens displays various forms of Betawi culture at private and public events. Private events include wedding ceremonies and inauguration ceremonies, while public events include Betawi cultural festivals or Lenong competitions. This foundation establishment is an important step for the sustainability of the studio, since traditional art could not survive without following the system and modernization. Instead of maintaining the rigidity of tradition, they need to be adaptive to the system, the development of the entertainment industry, and the technology.
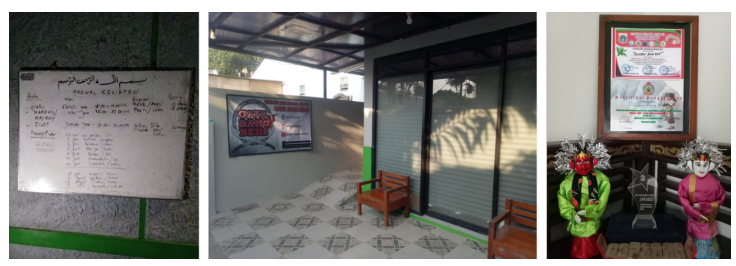

Figure 10 Sanggar Gaya Bang Bens’ office. Source: Sanggar Gaya Bang Bens

Sanggar Gaya Bang Bens actively uploads their Palang Pintu performances on their YouTube channel under the name SanggarBanBensOfficial. Through this account, the name Sanggar Gaya Bang Bens became known to the general public outside the Jakarta area. Until July 2021, the number of subscribers of the account was 30.4 thousand subscribers. From the videos on social media, the Indonesian people are interested in organizing Palang Pintu and contacted them through their social media account. 


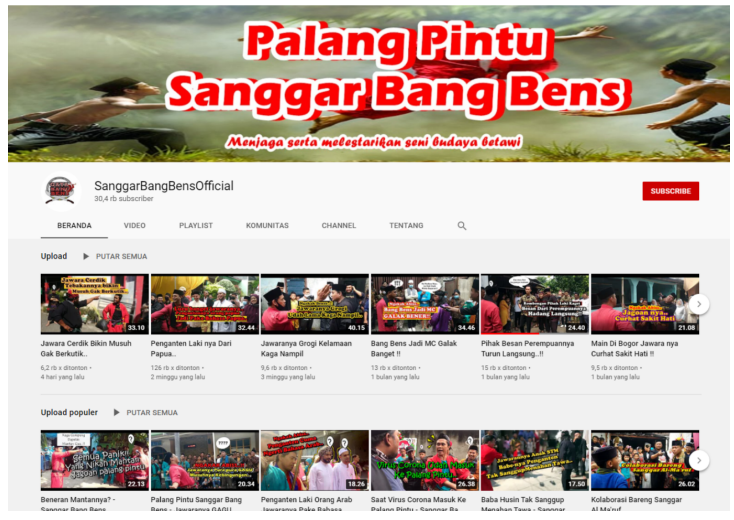

Figure 11 Youtube Account Sanggar Gaya Bang Bens. Source: Youtube.

At the beginning of the development of Palang Pintu in Rawa Belong, Sanggar Gaya Bang Bens saw the potential of Palang Pintu as a source of livelihood because most of the members were already able to do silat and recite Al-Quran. That makes it easy to learn Palang Pintu. In the early days of their performance, members of the Bang Bens Style Studio received a boxed rice/besek as a wage for their performance. Over time the honorarium earned can be used to make uniforms and become wages for each member. The good management of Sanggar Gaya Bang Bens is an important factor that made this sanggar stand to this day.

Optimization of social media also sharpens the skills of its members in recording and editing videos. With this capability, Sanggar Gaya Bang Bens can place advertisements on its Youtube videos and earn additional income. Combining traditional arts with technology is the right step not only to preserve, but also to develop the Palang Pintu tradition in the midst of the onslaught of popular culture. The development of Palang Pintu through the Sanggar Gaya Bang Bens was well received by the people of Rawa Belong. Young people in Rawa Belong are interested in learning silat and Palang Pintu, seeing that this tradition can not only preserve Betawi culture but also open up income opportunities for them. The parents felt the same way. In the midst of today's developments in technology and games, parents are happy to see their children learn silat, AlQuran, and Palang Pintu instead of playing with gadgets. Through the regular presence of new members, Sanggar Gaya Bang Bens not only regenerates its members but also develops and preserves Palang Pintu to the younger generation.

\section{CONCLUSIONS}

According to the primary data, it is illustrated that Sanggar Gaya Bang Bens has re-created and commodified the Palang Pintu tradition, compared to the origin of Palang Pintu in the 1990s. This tradition came to the Betawi community in Rawa Belong in the 1990s and brings two important elements, silat and Al-Quran recitation, which have been characteristics of the Betawi people. Thus, Palang Pintu is well received in the Rawa Belong area, West Jakarta, because it is the residence of ulama and jawara silat of Betawi.

The process of recreation is the best way to keep the tradition existing and to be known by people outside the Betawi ethnicity. The recreation process carried out includes incorporating elements of Lenong and comedy as well as using common language and diction in their pantun, which makes Palang Pintu relate to wider community and ethnicity. Other modified elements are its musical instruments from Rebana Ketimpring to Marawis Hadro, costume colors, and attribute Kembang Kelapa. These modifications make Palang Pintu from Sanggar Gaya Bang Bens become interesting, enjoyable, and understood by both Betawi and nonBetawi ethnic communities.

On the other hand, the commodification process brings Palang Pintu closer to its audiences. Sanggar Gaya Bang Bens with its signature Palang Pintu carries out promotions through uploading videos on Youtube and optimizing the Instagram account. From these videos, the popularity of Sanggar Gaya Bang Bens increased and made them receive many requests to perform. The modified Palang Pintu can be practiced widely and fluidly, not only for Betawi traditional wedding ceremonies but also inauguration ceremonies and circumcision celebrations. For performances, Sanggar Gaya Bang Bens applies a variable rate. The Palang Pintu tradition in Rawa Belong continues to be preserved and in demand by the people of Rawa Belong, it can be seen from the interest of Betawi youth to learn it and the good response of their parents. For them, studying Palang Pintu is not only able to preserve Betawi traditions but also opens up job opportunities for the younger generation in Rawa Belong. Based on the number of video views on his Youtube account, it can be seen that many people are also interested in inviting Sanggar Gaya Bang Bens to appear in their events. Seeing from its development until 2021, it can be assumed that this tradition is still in demand by the Indonesian people. It concludes that the spirit to preserve their culture 
comes from themselves by making the culture a commodity, and creating a sustainable activities.

\section{AUTHORS' CONTRIBUTIONS}

DR done the literature studies, field research, and interview, as well as wrote the manuscript and provided data for Table 1. NYD checked the art and cultural analyses. All authors reviewed the final manuscript.

\section{ACKNOWLEDGEMENTS}

In accordance with ICON ARCCADE 2021 The $2^{\text {nd }}$ International Conference on Art, Craft, Culture and Design, we would like to take this opportunity to thank for the effort and expertise from the committee. Your dedication is most appreciated as the number of manuscripts is increasing every year.

We would also show our gratitude to Yayasan Seni Budaya Gaya Bang Bens for the help and hospitality during the interview process. Your cooperation enables us to meet the primary datas to be analyzed in this article.

\section{REFERENCES}

[1] Shahab, Y., Alih Fungsi Seni Dalam Masyarakat Kompleks Kasus Liang-Liong Dan Barongsai. Antropologi Indonesia 61. 2000. p. 37-46.

[2] Erwantoro, H., Etnis Betawi: Kajian Historis. Patanjala Vol. 6 No. 1, 2014, p. 1-16.

[3] Shahab, Y., Rekacipta Tradisi Betawi: Sisi Otoritas dalam Proses Nasionalisasi Tradisi Lokal. Antropologi Indonesia 66, 2001, p. 4657.

[4] Fairclough, N., Critical Discourse Analysis and the Marketization of Public Discourse: The Universities. Discourse and Society, 1993.

[5] Morgan, T., Adorno and the Political Economy of Communication. The Political Economy of Communication Vol.1 No.2, 2013, p. 44-64.

[6] Kruger, S., Ethnography in the Performing Arts. JMU/Palatine, 2008.

[7] Erwantoro, H., Etnis Betawi: Kajian Historis. Patanjala Vol. 6 No. 1, 2014, p. 1-16.

[8] Anggraeni, D., Membangun Peradaban Bangsa Melalui Religiusitas Berbasis Budaya Lokal (Analisis Tradisi Palang Pintu Pada Budaya Betawi), Jurnal Studi Al-Qur'an Membangun Tradisi Berfikir Qur'ani Vol. 15 No.1, 2019.

[9] Anggraeni, D., Membangun Peradaban Bangsa Melalui Religiusitas Berbasis Budaya Lokal
(Analisis Tradisi Palang Pintu Pada Budaya Betawi), Jurnal Studi Al-Qur'an Membangun Tradisi Berfikir Qur'ani Vol. 15 No.1, 2019.

[10] Shahab, Y., Rekacipta Tradisi Betawi: Sisi Otoritas dalam Proses Nasionalisasi Tradisi Lokal. Antropologi Indonesia 66, 2001, p. 4657.

[11] Anggraeni, D., Membangun Peradaban Bangsa Melalui Religiusitas Berbasis Budaya Lokal (Analisis Tradisi Palang Pintu Pada Budaya Betawi), Jurnal Studi Al-Qur'an Membangun Tradisi Berfikir Qur'ani Vol. 15 No.1, 2019.

[12] Amanah, W., Konstruksi Sosial Pemaknaan Pangsi Jawara Betawi: Penguatan Identitas Etnis Betawi dalam Menghadapi Globalisasi. Universitas Islam Negeri Syarif Hidayatullah, 2018.

[13] Melinda, A., Makna Simbolik Palang Pintu Pada Pernikahan Etnis Betawi di Setu Babakan. Koneksi Vol. 2 No. 2, 2018, p. 218225.

[14] Permana, C. E., Rupa Gaya Rasa Betawi. Universitas Indonesia, 2010, p. 78.

[15] Ostherr, K., Artificial Mythologies: A Guide to Cultural Invention. College Literature Vol. 25 No. 3, 1998, p. 194.

[16] Shahab, Y., Rekacipta Tradisi Betawi: Sisi Otoritas dalam Proses Nasionalisasi Tradisi Lokal. Antropologi Indonesia 66, 2001, p. 4657.

[17] Minawati, R., Komodifikasi: Manipulasi Budaya Dalam (Ajang) Pariwisata. Jurnal Ekspresi Seni Vol. 15 No. 1, 2011, p. 117-127.

[18] Minawati, R., Komodifikasi: Manipulasi Budaya Dalam (Ajang) Pariwisata. Jurnal Ekspresi Seni Vol. 15 No. 1, 2011, p. 117-127. 